\title{
Identification of lactic acid bacteria with bio-preservative potential isolated from contaminated avian blood obtained at the slaughterhouse
}

\author{
Identificación de bacterias ácido lácticas con potencial biopreservador aisladas a partir de \\ sangre aviar obtenida en mataderos
}

\author{
MV Zbruna, MG Altina ${ }^{\mathrm{a}}$, E Bonansea ${ }^{\mathrm{a}}$, LS Frizzo ${ }^{\mathrm{a}, \mathrm{b}}$, LP Soto ${ }^{\mathrm{a}, \mathrm{b}}$, A Romero-Scharpen ${ }^{\mathrm{a}}$, \\ MR Rosmini ${ }^{a, c}$, GJ Sequeira ${ }^{a}$ ML Signorini ${ }^{a, b^{*}}$

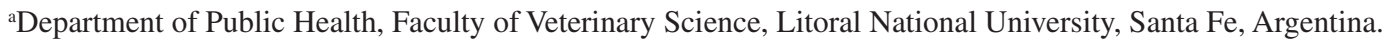 \\ ${ }^{b}$ National Council of Scientific and Technical Research, Argentina. \\ ${ }^{\mathrm{c}}$ Faculty of Agricultural Science, Catholic University of Cordoba, Province of Cordoba, Argentina.
}

\begin{abstract}
RESUMEN
La sangre es uno de los residuos más contaminantes de la industria cárnica, y a la vez es tiene diversas aplicaciones en la industria alimenticia animal. No obstante, dado que la sangre es altamente susceptible a la descomposición microbiana, ella y sus fracciones suelen no estar disponibles para su uso como ingredientes en la industria alimenticia. La biopreservación se presenta como una alternativa para mejorar la calidad de la sangre y de esta forma presentarla como un ingrediente en la elaboración de productos alimenticios. El objetivo de este trabajo fue aislar e identificar bacterias ácido lácticas (BAL) a partir de sangre aviar obtenida en mataderos industriales y evaluar su actividad antimicrobiana. Se aislaron 96 colonias presuntivas de BAL a partir de sangre aviar, las cuales fueron genotipificadas. Se estudiaron 31 BAL obtenidas a partir de diferentes muestras de sangre y se identificaron 11 grupos de bacterias diferentes a partir del análisis de restricción del ADN microbiano. De éstas, 28 produjeron compuestos antimicrobianos como ácidos orgánicos, 11 generaron peróxido de hidrógeno $\left(\mathrm{H}_{2} \mathrm{O}_{2}\right)$ y dos fueron productoras de sustancias tipo bacteriocinas. Estas últimas, identificadas como Lactobacillus salivarius (DSPV 027SA) y Enterococcus faecalis (DSPV 008SA), inhibieron el crecimiento de Escherichia coli, Pseudomonas aeruginosa y algunos serotipos de Salmonella spp. De esta forma se lograron identificar dos cepas de BAL como potenciales candidatas para ser aplicadas en un sistema de biopreservación de sangre aviar. Esta herramienta biotecnológica es más económica que otras técnicas de sanitización y reduciría el riesgo de transmisión de microorganismos patógenos a lo largo de la cadena agroalimentaria.
\end{abstract}

Palabras clave: bacterias ácido lácticas, sangre aviar, biopreservación, bacteriocinas.

\section{SUMMARY}

Blood is a common by-product of the meat industry, which has several potential applications in the animal feed industry. However, since blood is highly susceptible to microbial spoilage, blood and its fractions are often not suitable ingredients for the feed industry. Biopreservation appears as an alternative for the improvement of blood's quality towards its use as an ingredient in foodstuff. The objective of this work was to isolate and identify Lactic Acid Bacteria (LAB) in avian blood obtained from industrial slaughterhouses and evaluate their antimicrobial activity. Ninety-six LAB were isolated from avian blood and genotyped. Eleven Amplified rDNA Restriction Analysis groups were identified. Between two and five different species were detected in each blood sample (31 strains in all blood samples) which were selected to study antagonistic activity. Twenty-eight of them produced antimicrobial compounds such as organic acids, 11 strains produced hydrogen peroxide $\left(\mathrm{H}_{2} \mathrm{O}_{2}\right.$ and two released bacteriocin-like compounds. The latter, identified as Lactobacillus salivarius (DSPV 027SA) and Enterococcus faecalis (DSPV 008SA), inhibited the growth of Escherichia coli, Pseudomonas aeruginosa and some serotypes of Salmonella spp. These two LAB strains would be candidates for potential application as a blood biopreservation system. This biotechnological tool is cheaper than others sanitation techniques and could reduce the risk of pathogens transmission thought food chain.

Key words: lactic acid bacteria, avian blood, biopreservation, bacteriocins.

\section{INTRODUCTION}

In Argentina, more than 615 million poultries are slaughtered every year ${ }^{1}$, producing more than 123 million

Accepted: 09.05.2013.

* Kreder 2805, (S3080HOF) Esperanza, Provincia de Santa Fe, Argentina; marcelo.signorini@gmail.com

1 MINAGRI, Ministerio de Agricultura de la República Argentina, http://www.minagri.gob.ar/SAGPyA/ganaderia/aves/index.php (accessed 17 July 2010). liters of blood. Taking into account a typical protein content of around 18\% (Putnam 1975), this volume of blood is equivalent to a production of 11,500 tons of protein. This blood is considered a by-product that can be used as a raw material in both feed and food industries because of its excellent nutritional value and functional properties (Dávila et al 2006). It can be considered as a good food additive (or ingredient) due to its high protein content and even shows an efficacy index larger than casein. Also, blood has high iron content bound to hemog- 
lobin, which is the best bioavailable form (Reizenstein 1980).

However, spoilage and pathogenic microorganisms such as Salmonella spp, E. coli and Pseudomona spp from feathers, skin and gut from slaughtered animals can reach the blood and rapidly grow in this rich medium (Carretero and Parés 2000, Dávila et al 2006). This happens when meat industries (mainly avian slaughterhouses) have no suitable facilities to properly collect and handle blood, therefore, contamination is unavoidable even under strict hygienic conditions. Blood is harvested by open system and for this reason, contamination is impossible to prevent.

The quality of blood can be improved by different methods. One possibility is to use lactic acid bacteria (LAB) to control bacterial populations and increase the shelf life of blood. This alternative has been reported in different areas of the food industry, and frequently in meat products (Signorini et al 2006). The mode of action of LAB includes competence for nutrients, adhesion to the substrate and production of antibacterial compounds such as organic acids, diacetyl, hydrogen peroxide, reuterin and bacteriocins. Therefore, LAB strains isolated from the same product in which they will be subsequently used as biopreservative agents (with the subsequent reduction in the use of antibiotics) may have the greatest success in controlling both pathogenic and spoilage microorganisms (Signorini et al 2006).

This study aimed to isolate and identify LAB strains in avian blood obtained from industrial slaughterhouses and perform a preliminary evaluation of their antimicrobial activity. The application of biopreservation cultures to blood could reduce the microbiological load, extending its shelf life, and thus avoiding immediate processing after blood collection. Poultry slaughterhouses could thus use blood efficiently, transforming it into a product with high biological value.

\section{MATERIAL AND METHODS}

\section{ISOLATION OF LAB}

Ten avian blood samples from two slaughterhouses were collected directly from the slaughter line. Samples were kept on ice and immediately transferred to the laboratory for bacterial isolation. Blood samples were serially diluted in sterile Ringer $1 / 4$ solution, pour-plated in Petri plates with MRS agar (OXOID) and LAMBAV agar (Hartemink et al 1997) as culture media, and then incubated under anaerobic conditions in anaerobic jars with Anaerocult A gas packs (Merck, Darmstadt, Germany), at $37^{\circ} \mathrm{C}$ for $48 \mathrm{~h}$.

Colonies from each plate were randomly picked to obtain pure cultures on MRS broth (OXOID) and incubated at $37^{\circ} \mathrm{C}$ for $48 \mathrm{~h}$ under anaerobic conditions. Gram staining and catalase test were performed as a preliminary screening for $\mathrm{LAB}$. For preservation, the cultures were frozen at $-80^{\circ} \mathrm{C}$ with the addition of glycerol $25 \% \mathrm{v} / \mathrm{v}$.

\section{GENOTYPING OF ISOLATED LAB}

DNA from presumptive LAB was isolated following the protocol reported by Marmur (1961) modified by Kurzak et al (1998) to amplify the 16S rDNA (1500 bp). To characterize the isolates, an Amplified rDNA Restriction Analysis (ARDRA) was conducted (Soto et al 2010). Amplification of the 16S rDNA was performed using 20 to $50 \mathrm{ng}$ of DNA in $25 \mu \mathrm{L}$ reactions containing 1.5 $\mathrm{mM} \mathrm{MgCl}, 200 \mu \mathrm{M}$ each deoxynucleoside triphosphates (Promega), $0.4 \mu \mathrm{M}$ each of primers $27 \mathrm{f}$ and $1492 \mathrm{r}$ (Kim and Chun, 2005) and 1 U Taq polymerase (GoTaq, Promega) in $1 \mathrm{X} \mathrm{Taq}$ buffer (Promega). The reaction mixtures were incubated in a Thermal Cycler (MJ Research). The amplification conditions were as follows: $94^{\circ} \mathrm{C}$ for $5 \mathrm{mi}$ nutes, 30 cycles of $94^{\circ} \mathrm{C}$ for 1 minute, $55^{\circ} \mathrm{C}$ for 1 minute and $72^{\circ} \mathrm{C}$ for 1 minute, and a final extension step at $72^{\circ} \mathrm{C}$ for 7 minute. After cycling, the PCR products were visualized by electrophoresis on a $1 \% \mathrm{w} / \mathrm{v}$ agarose gel $(40 \mathrm{mi}-$ nutes, $75 \mathrm{~V})$, by staining with Gel Red ( $1 \mu \mathrm{L}$ in $10 \mathrm{ml})$ and visualizing under UV light (DyNA Light UV Transilluminator, LabNet, UV light source wavelength $302 \mathrm{~nm}$ ).

Then, a $15-\mu \mathrm{L}$ aliquot of each PCR reaction was incubated for $37^{\circ} \mathrm{C}$ for $4 \mathrm{~h}$ with $2 \mu \mathrm{L}$ of $10 \mathrm{X}$ incubation buffer, $0.2 \mu \mathrm{L}$ of bovine serum albumin, $2.5 \mu \mathrm{L}$ of bidistilled water and $6 \mathrm{U}$ of one of the following restriction enzymes: Hinf I, Hae III, or Msp I.

The restriction products were analyzed by electrophoresis in 2\% agarose gel. During the analysis of ARDRA patterns, bands with the same gel mobility were considered equivalent, independently of their relative intensity. The results of the separate restriction profiles were combined into a single dataset and analyzed using the Unweighted Pair Group Method with Arithmetic mean (UPGMA) algorithm by Treecon for Windows (Version 1.3b, Yves Van de Peer, University of Konstanz, Germany).

Afterwards, isolates with $16 \mathrm{~S}$ rDNA restriction profiles different for each blood sample were purified with Wizard PCR SV Gel \& PCR Clean-Up System kit (Promega) and sequenced. Isolates were then identified by partial sequence using the GenBank BLAST alignment software ${ }^{2}$.

\section{ANTAGONISTIC ACTIVITY TESTS}

LAB with different ARDRA profiles were inoculated on MRS Broth at $37^{\circ} \mathrm{C}$ for $16 \mathrm{~h}$. Then the cultures were centrifuged and the supernatants were collected (Cell Free Extract, $\mathrm{CFE}$ ), and one aliquot of this was adjusted to $\mathrm{pH}$ 6.00 - 6.50 with 3M NaOH (Cell Free Neutralizing Extract, CFNE). Seven strains origins of DSP (Public Healthy Department, Faculty of Veterinary, University of Litoral, Argentina) Laboratory collection were used as indicator of microorganisms: Escherichia coli (GenBank accession number FJ997269), Salmonella Dublin (GenBank acces-

http://www.ncbi.nlm.nih.gov/BLAST 
sion number FJ997268), Pseudomonas fluorescens ATCC DSM50106, Lactobacillus casei (GenBank accession number: FJ787305), Lactobacillus plantarum (GenBank accession number: FJ751793), Enterococcus faecium (Schneider et al 2004), and Lactobacillus acidophilus (DSP collection). E. coli, S. Dublin and P. fluorescens were selected because they are related to slaughterhouse blood contamination and they present negative effects in the microbiological quality of this product (Zamora-Rodriguez 2003). Also, these bacteria are potential human and animal pathogens.

An agar well diffusion assay was used for detection of antagonistic activity (De Vuyst et al 1996), MRS or BHI (Brain Heart Infusion) soft agar (0.8 g/100 g agar) plates were used (MRS for L. casei, L. plantarum, E. faecium, and L. acidophilus, and BHI for E. coli, S. Dublin, and $P$. fluorescens). The soft agar was inoculated previously with an overnight culture of each indicator strain. Holes $5 \mathrm{~mm}$ in diameter were cut into these agar plates and CFE and CFNE from the isolates was placed $(30 \mu \mathrm{l})$ into each well. The plates were then incubated under aerobic conditions at $37^{\circ} \mathrm{C}$ for $48 \mathrm{~h}$ and subsequently examined for zones of inhibition ( $2 \mathrm{~mm}$ clear or larger zones around the well were scored as positive inhibition).

\section{HYDROGEN PEROXIDE PRODUCTION}

To elucidate whether the antimicrobial activity derives from the production of hydrogen peroxide by LAB, each LAB with antimicrobial activity was evaluated with the hydrogen peroxide test (McLean and Rosenstein 2000). MRS agar supplemented with $0.25 \mathrm{mg} / \mathrm{ml}$ of tetramethylbenzidine (TMB, Sigma) and $0.01 \mathrm{mg} / \mathrm{ml}$ of horseradish peroxidase (HRP, Sigma) was inoculated with LAB and incubated anaerobically for $48 \mathrm{~h}$ at $37^{\circ} \mathrm{C}$. The plates were then air exposed for 30 minutes. Colonies that produced hydrogen peroxide were blue due to TMB oxidation.

\section{DETECTION, CHARACTERIZATION OF BACTERIOCINS AND EVALUATION OF ANTAGONIST ACTIVITY AGAINST PATHOGENIC MICROORGANISMS FREQUENTLY ISOLATED FROM THE AVIAN CHAIN}

The sensitivity to proteolytic enzymes of the CFNE was investigated adding Proteinase K (Sigma) at a final concentration of $1 \mathrm{mg} / \mathrm{mL}$ (Todorov and Dicks 2006). Samples with and without proteases were incubated at $37^{\circ} \mathrm{C}$ for $24 \mathrm{~h}$ and residual activity was determined. The absence of inhibition zone in the presence of the protease confirmed the polypeptide nature of the antibacterial substances.

To test the influence of $\mathrm{pH}$, the CFNE were adjusted to $\mathrm{pH} 4.0,5.0,6.0,7.0,8.0$, and 9.0 with $\mathrm{HCl} 3 \mathrm{M}$ or $\mathrm{NaOH} 3 \mathrm{M}$ (Sigma), and allowed to stand at room temperature for 30 and 90 minutes. The effect of temperature on CFNE stability was determined by treatment in a water bath at $90^{\circ} \mathrm{C}$ and $121^{\circ} \mathrm{C}$ for 30 and 15 minutes, respectively (Todorov and Dicks 2006).
The antagonistic activity test was performed against pathogenic microorganisms frequently isolated from the avian chain to study the inhibition spectra, specifically of each LAB producing bacteriocin-like compounds. Sources of these strains are shown in table 1 .

The presence of enterocin-encoding genes was studied by PCR amplification with primers for enterococcal bacteriocins (Du Toit et al 2000). Total genomic DNA from strains was used. PCR products were analyzed by electrophoresis ( $85 \mathrm{~V}$ for $1 \mathrm{~h} 5 \mathrm{~min}$ ) on $2 \%(\mathrm{w} / \mathrm{v})$ agarose gels in TAE buffer. Gels were stained GelRed (Invitrogen) and observed under UV light. The sizes of the amplified fragments were determined using 100-bp DNA Ladder (Promega) as a molecular weight marker.

\section{RESULTS}

This work was structured in two parts. Firstly, LAB from slaughterhouse avian blood was isolated and genotyped and then the antimicrobial activity of the identified LAB was evaluated.

\section{ISOLATION OF LAB}

Ninety-six presumptive LAB strains (gram-positive, catalase-negative) were successfully isolated from a total of 10 avian blood samples taken on different days from two industrial slaughterhouses and the average concentration of this population was $4.94 \log \mathrm{CFU} / \mathrm{ml}(\mathrm{SD}=0.80)$ on MRS Agar and $3.95 \log \mathrm{CFU} / \mathrm{ml}(\mathrm{SD}=0.39)$ on LAMBAV Agar.

\section{GENOTYPING OF ISOLATED LAB}

PCR amplification of the 16S rDNA of the 96 isolates followed by analysis with three different restriction endonucleases was carried out (ARDRA). Each blood sample was analyzed individually with the aim to detect different

Table 1. Sources of pathogenic microorganisms isolated from the avian chain (autochthon indicator bacteria). SA = avian blood.

Fuente de microorganismos patógenos aislados de la cadena aviar (bacterias indicadores autóctonas). SA= Sangre Aviar.

\begin{tabular}{lc}
\hline \multicolumn{1}{c}{ Strains } & Origin \\
\hline Escherichia coli (SA) & Avian blood of slaughterhouse \\
Salmonella spp (SA) & Avian blood of slaughterhouse \\
Pseudomonas aeruginosa (SA) & Avian blood of slaughterhouse \\
Bacillus sp (SA) & Avian blood of slaughterhouse \\
Staphylococcus aureus (SA) & Avian blood of slaughterhouse \\
Salmonella muenchen & Avian egg \\
Salmonella gallinarum & Avian egg \\
Salmonella agona & Avian egg \\
Salmonella brandenburg & Avian egg \\
Salmonella enteritidis & Avian egg \\
Salmonella typhimurium & Avian egg \\
\hline
\end{tabular}


species of LAB in samples taken on different days. In this way, between two and five different species were detected in each sample (31 strains in all blood samples).

ARDRA revealed different profiles having three to six fragments ranging in size from 60 to 1000 bp for different isolates and grouped all isolates into 11 species groups using Treecon ${ }^{\circledR}$ Software (figure 1). Restriction digestion of the amplified product with different enzymes revealed that Msp I was more discriminatory.

The most frequently detected species in the slaughterhouse blood samples were Lactobacillus salivarius and Enterococcus faecalis (7 out of 10 samples had these species). Finally, isolates with different ARDRA profiles into blood samples were sequenced and submitted to GenBank (table 2).

\section{ANTAGONISTIC ACTIVITY TESTS}

Ninety percent (28/31) of the identified and tested LAB strains showed antimicrobial activity against one or more indicator strain from DSP Laboratory collection by agar well diffusion assay, and only three strains showed no antagonistic activity (table 3). Eleven of the strains with antimicrobial activity showed activity in the CFNE. Regarding the indicator strains, L. case $i$ was not inhibited by any CFE, whereas L. acidophilus was affected by $10 \%$ of CFE and not affected by any CFNE. Regarding the other LAB, L. plantarum was inhibited by $16 \%$ of CFE and $10 \%$ of CFNE, whereas E. faecium was inhibited by $48 \% \mathrm{CFE}$ and $3 \% \mathrm{CFNE}$. With regards to pathogens, $E$. coli and Salmonella Dublin were inhibited by $68 \%$ and $77 \%$ of CFE, respectively. However, only one CFNE inhibited $S$. Dublin. In contrast, $P$. fluorescens was inhibited by $55 \%$ of CFE and $23 \%$ of CFNE.

\section{HYDROGEN PEROXIDE PRODUCTION}

Eleven strains with antimicrobial activity in CFNE (gray in table 3) were analyzed for $\mathrm{H}_{2} \mathrm{O}_{2}$ production. Eighty percent of these strains were positive before 10 minutes of air exposure. Only L. salivarius (DSPV 027SA) and E. faecalis (DSPV 008SA) were negative to $\mathrm{H}_{2} \mathrm{O}_{2}$ production. Therefore, antimicrobial activities of these two strains might be due to the production of bacteriocin-like compounds.

\section{DETECTION, CHARACTERIZATION OF BACTERIOCINS AND EVALUATION OF ANTAGONIST ACTIVITY AGAINST PATHOGENIC MICROORGANISMS FREQUENTLY ISOLATED FROM THE AVIAN CHAIN}

To study the inhibitory compounds of $L$. salivarius (DSPV 027SA) and E. faecalis (DSPV 008SA), CFNE were incubated with proteinase $\mathrm{K}$. Results showed that antimicrobial effect disappeared after this assay, confirming proteinaceus bacteriocin-like substances. Then,
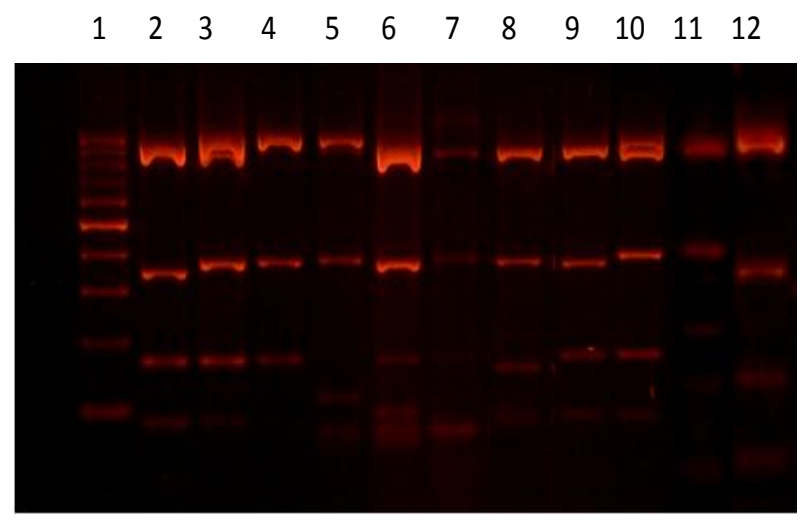

(a)

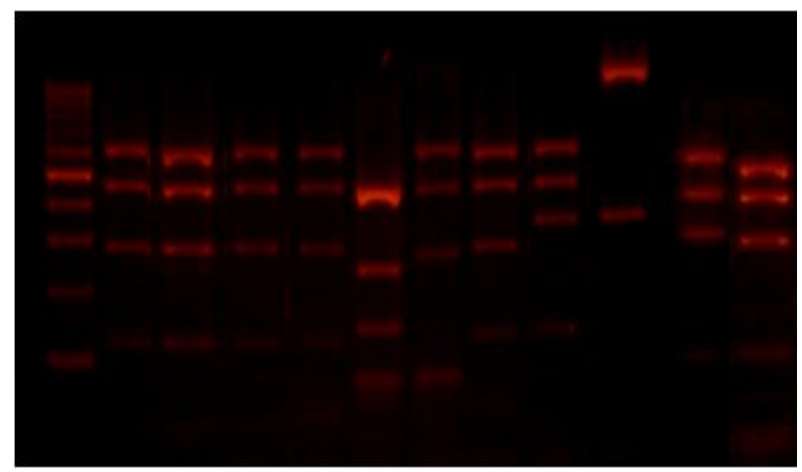

(b)

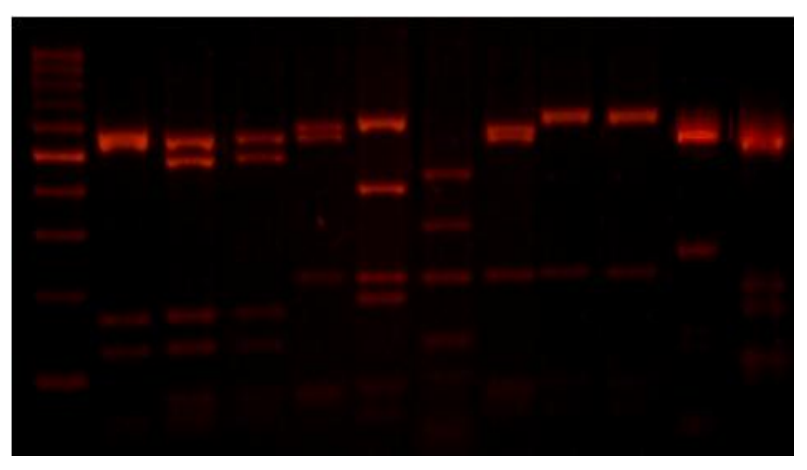

Figure 1. LAB isolated from slaughterhouse avian blood: agarose gel with different groups of ARDRA.

BAL aisladas de sangre de matadero aviar: gel de agarosa con los diferentes grupos de ARDRA.

References: Line $1 \mathrm{MW}$ ladder (100 bp); line 2, ARDRA group 1 (E. faecalis); line 3, ARDRA group 2 (E. faecium); line 4, ARDRA group 3 (E. durans); line 5, ARDRA group 4 (L. brevis); line 6, ARDRA group 5 (L. crispatus); line 7, ARDRA group 6 (L. reuteri); line 8, ARDRA group 7 (L. salivarius); line 9, ARDRA group 8 (P. acidilactici); line 10, ARDRA group 9 (W. paramesenteroides); line 11, ARDRA group 10 (P.pentosaceus); line 12, ARDRA group 11 (L. plantarum). Restriction fragments obtained with each enzyme: (a) Hinf I, (b) Hae III, (c) Msp I. 
Table 2. List of bacteria isolated in this study and their closest affiliation according to the 16S rDNA sequencing (1500 bp) or by belonging to the same ARDRA group.

Listado de bacterias aisladas en el estudio y su afiliación de acuerdo a la secuenciación del gen 16rADN (1500 pb) o en función del mismo grupo según ARDRA.

\begin{tabular}{|c|c|c|c|c|c|}
\hline Strains & Species group & ARDRA Group & Identity Value & Blood Samples & Accession number \\
\hline DSPV 001SA & Enterococcus durans & 1 & $94 \%$ & 4 & JQ322216 \\
\hline DSPV 002SA & Enterococcus faecalis & 2 & $97 \%$ & 8 & JQ322217 \\
\hline DSPV 003SA & Enterococcus faecalis & 2 & $99 \%$ & 2 & JQ322220 \\
\hline DSPV 004SA & Enterococcus faecalis & 2 & $99 \%$ & 1 & JQ322221 \\
\hline DSPV 005SA & Enterococcus faecalis & 2 & $99 \%$ & 3 & JQ322222 \\
\hline DSPV 006SA & Enterococcus faecalis & 2 & $97 \%$ & 4 & JQ322212 \\
\hline DSPV 007SA & Enterococcus faecalis & 2 & $98 \%$ & 10 & JQ322214 \\
\hline DSPV 008SA & Enterococcus faecalis & 2 & $100 \%$ & 5 & JQ322228 \\
\hline DSPV 009SA & Enterococcus faecium & 3 & $99 \%$ & 6 & JQ322238 \\
\hline DSPV 010SA & Enterococcus faecium & 3 & $99 \%$ & 4 & JQ322235 \\
\hline DSPV 011SA & Enterococcus faecium & 3 & $95 \%$ & 7 & JQ322213 \\
\hline DSPV 012SA & Lactobacillus brevis & 4 & $94 \%$ & 4 & JQ322211 \\
\hline DSPV 013SA & Lactobacillus crispatus & 5 & $98 \%$ & 7 & JQ322240 \\
\hline DSPV 014SA & Lactobacillus plantarum & 6 & $99 \%$ & 3 & JQ322237 \\
\hline DSPV 016SA & Lactobacillus reuteri & 7 & $99 \%$ & 9 & JQ322218 \\
\hline DSPV 017SA & Lactobacillus reuteri & 7 & $99 \%$ & 10 & JQ322219 \\
\hline DSPV 018SA & Lactobacillus reuteri & 7 & $99 \%$ & 8 & JQ322226 \\
\hline DSPV 019SA & Lactobacillus reuteri & 7 & $99 \%$ & 5 & JQ322227 \\
\hline DSPV 020SA & Lactobacillus reuteri & 7 & $99 \%$ & 6 & JQ322209 \\
\hline DSPV 021SA & Lactobacillus salivarius & 8 & $100 \%$ & 2 & JQ322239 \\
\hline DSPV 022SA & Lactobacillus salivarius & 8 & $98 \%$ & 4 & JQ322236 \\
\hline DSPV 023SA & Lactobacillus salivarius & 8 & $99 \%$ & 9 & JQ322241 \\
\hline DSPV 024SA & Lactobacillus salivarius & 8 & $99 \%$ & 10 & JQ322242 \\
\hline DSPV 025SA & Lactobacillus salivarius & 8 & $99 \%$ & 1 & JQ322225 \\
\hline DSPV 026SA & Lactobacillus salivarius & 8 & $99 \%$ & 5 & JQ322229 \\
\hline DSPV 027SA & Lactobacillus salivarius & 8 & $99 \%$ & 6 & JQ322208 \\
\hline DSPV 015SA & Pediococcus acidilactici & 9 & $99 \%$ & 3 & JQ322207 \\
\hline DSPV 028SA & Pediococcus acidilactici & 9 & $99 \%$ & 4 & JQ322215 \\
\hline DSPV 029SA & Pediococcus pentosaceus & 10 & $99 \%$ & 1 & JQ322223 \\
\hline DSPV 030SA & Pediococcus pentosaceus & 10 & $99 \%$ & 10 & JQ322224 \\
\hline DSPV 031SA & Weissella paramesenteroides & 11 & $96 \%$ & 6 & JQ322210 \\
\hline
\end{tabular}


Table 3. Antimicrobial effects of the supernatants of lactic acid bacteria isolated from slaughterhouse blood before (Cell Free Extract, CFE) and after neutralization (Cell Free Neutralizing Extract, CFNE) against strains of DSP Laboratory collection (DSP collection indicator bacteria). Grey color indicates strains with CFNE diameter halo was over $2 \mathrm{~mm}$.

Efecto antimicrobiano del sobrenadante de las bacterias ácido lácticas aisladas a partir de sangre aviar de mataderos antes (Extracto Libre de Células, ELC) y después de la neutralización (Extracto Libre de Células Neutralizado, ELCN) contra cepas de la colección del Laboratorio del DSP (bacterias indicadores de colección). El color gris indica halos de inhibición de CFNE con diámetros mayores a 2 mm.

\begin{tabular}{|c|c|c|c|c|c|c|c|c|c|c|c|c|c|c|c|}
\hline \multirow[b]{2}{*}{ Strain } & \multirow[b]{2}{*}{ Species } & \multicolumn{2}{|c|}{ L. casei } & \multicolumn{2}{|c|}{ L plantarum } & \multicolumn{2}{|c|}{ E. faecium } & \multicolumn{2}{|c|}{ L. acidophilus } & \multicolumn{2}{|c|}{ E. coli } & \multicolumn{4}{|c|}{ Salmonella dublin P. fluorescens } \\
\hline & & CFE & CFNE & CFE & CFNE & CFE & CFNE & CFE & CFNE & $\mathrm{CFE}$ & CFNE & CFE & CFNE & CFE & CFNE \\
\hline DSPV 001SA & Enterococcus durans & - & - & - & - & + & - & - & - & + & - & + & - & - & - \\
\hline DSPV 002SA & Enterococcus faecalis & - & - & - & - & - & - & - & - & - & - & - & - & - & - \\
\hline DSPV 003SA & Enterococcus faecalis & - & - & - & - & - & - & - & - & - & - & + & - & + & + \\
\hline DSPV 004SA & Enterococcus faecalis & - & - & - & - & - & - & - & - & - & - & - & - & - & - \\
\hline DSPV 005SA & Enterococcus faecalis & - & - & - & - & + & - & - & - & + & - & - & - & - & - \\
\hline DSPV 006SA & Enterococcus faecalis & - & - & - & - & - & - & - & - & + & - & - & - & - & - \\
\hline DSPV 007SA & Enterococcus faecalis & - & - & - & - & - & - & - & - & + & - & + & - & + & - \\
\hline DSPV 008SA & Enterococcus faecalis & - & - & - & - & - & - & - & - & - & - & - & - & + & + \\
\hline DSPV 009SA & Enterococcus faecium & - & - & - & - & + & - & - & - & + & - & + & - & + & - \\
\hline DSPV 010SA & Enterococcus faecium & - & - & - & - & - & - & - & - & - & - & + & - & + & + \\
\hline DSPV 011SA & Enterococcus faecium & - & - & - & - & - & - & - & - & + & - & + & - & + & + \\
\hline DSPV 012SA & Lactobacillus brevis & - & - & - & - & - & - & - & - & - & - & - & - & - & - \\
\hline DSPV 013SA & Lactobacillus crispatus & - & - & - & - & - & - & - & - & - & - & - & - & + & + \\
\hline DSPV 014SA & Lactobacillus plantarum & - & - & - & - & + & + & - & - & - & - & + & - & - & - \\
\hline DSPV 015SA & Lactobacillus reuteri & - & - & + & + & - & - & - & - & + & - & + & - & - & - \\
\hline DSPV 016SA & Lactobacillus reuteri & - & - & + & - & - & - & - & - & + & - & + & - & - & - \\
\hline DSPV 017SA & Lactobacillus reuteri & - & - & - & - & + & - & - & - & + & - & + & - & + & - \\
\hline DSPV 018SA & Lactobacillus reuteri & - & - & + & - & + & - & + & - & + & - & + & - & + & - \\
\hline DSPV 019SA & Lactobacillus reuteri & - & - & - & - & + & - & + & - & + & - & + & - & + & + \\
\hline DSPV 020SA & Lactobacillus reuteri & - & - & + & + & + & - & - & - & + & - & + & + & + & - \\
\hline DSPV 021SA & Lactobacillus salivarius & - & - & - & - & - & - & - & - & - & - & + & - & - & - \\
\hline DSPV 022SA & Lactobacillus salivarius & - & - & - & - & + & - & - & - & + & - & + & - & + & - \\
\hline DSPV 023SA & Lactobacillus salivarius & - & - & - & - & + & - & - & - & + & - & + & - & + & + \\
\hline DSPV 024SA & Lactobacillus salivarius & - & - & - & - & + & - & - & - & + & - & + & - & + & - \\
\hline DSPV 025SA & Lactobacillus salivarius & - & - & - & - & + & - & - & - & + & - & + & - & - & - \\
\hline DSPV 026SA & Lactobacillus salivarius & - & - & - & - & + & - & + & - & + & - & + & - & + & - \\
\hline DSPV 027SA & Lactobacillus salivarius & - & - & + & + & + & - & - & - & + & - & + & - & - & - \\
\hline DSPV 028SA & Pediococcus acidilactici & - & - & - & - & - & - & - & - & - & - & + & - & - & - \\
\hline DSPV 029SA & $\begin{array}{l}\text { Pediococcus } \\
\text { pentosaceus }\end{array}$ & - & - & - & - & + & - & - & - & + & - & + & - & + & - \\
\hline DSPV 030SA & $\begin{array}{l}\text { Pediococcus } \\
\text { pentosaceus }\end{array}$ & - & - & - & - & - & - & - & - & + & - & + & - & + & - \\
\hline DSPV 031SA & $\begin{array}{c}\text { Weissella } \\
\text { paramesenteroides }\end{array}$ & - & - & - & - & - & - & - & - & + & - & + & - & - & - \\
\hline
\end{tabular}


CFNE from L. salivarius DSPV 027SA were not affected by different $\mathrm{pH}$. On the other hand, E. faecalis DSPV 008SA was affected by low $\mathrm{pH}(\mathrm{pH}=4.00$ and 5.00). CFNE from both strains remained active after heat treatment. Like most bacteriocins (Nettles and Barefoot 1993), all bacteriocin-like substances included in this study are resistant to high temperature. This biochemical characteristic is important if this substance is applied in process of feed or food industries.

On the other hand, L. salivarius DSPV 027SA and E. faecalis DSPV 008SA showed an important antimicrobial activity against autochthon indicator bacteria (table 1) such as Salmonella Agona, S. Brandenburg, Salmonella spp. (SA) and Pseuodomonas aeruginosa (SA). Only L. salivarius DSPV 027SA had antagonistic activity against $S$. Typhimurium when the test was performed. Regarding the other microorganisms tested, L. salivarius DSPV 027SA and E. faecalis DSPV 008SA showed no antimicrobial activity. The analyses of structural enterocins genes in the DNA of E. faecalis DSPV 008SA by PCR reactions was also done and revealed that the entA gen was amplified. The size of the fragment observed was $137 \mathrm{bp}$.

\section{DISCUSSION}

The slaughterhouse blood microbiota includes predominantly bacteria from gastrointestinal tracts (GIT) of animals and, in a lower percentage, environmental microorganisms. Therefore, it is important and useful studying the microbiota diversity existing in slaughterhouse blood because this product could contain beneficial microorganisms with preservation potential.

The importance of LAB in biopreservation has increased. Many LAB genera like Lactobacillus, Enterococcus, and Bacillus sp. are used as probiotics or in biopreservation in products for humans and animals (Chukeatirote 2003, Kolozyn-Krajewska and Dolatowski 2012, Delavenne et al 2013). In this study, LAB population from blood slaughterhouses was isolated and counted. LAB were in average $4.94 \log \mathrm{CFU} / \mathrm{ml}$ on MRS Agar and $3.95 \log \mathrm{CFU} / \mathrm{ml}$ on LAMVAB. This indicates that Lactobacillus spp count on LAMVAB plates represent a major part of all LAB that growth on MRS agar. Lactobacillus is one of the LAB genus that generally occur in traditional fermented foods, this factor must be taken into consideration when evaluating the use as biopreservative (Holzapfel 1997).

Various species of LAB, reported as being predominant in chicken GIT, can contaminate the slaughterhouse in the evisceration process. ARDRA has been used to compare bacterial isolates within a wide range of microbial communities. The advantages of ARDRA are that it is rapid, reproducible, relates to microbial diversity, and is invaluable in analyzing a large number of samples together (Ziemer et al 2004).
In this work, ARDRA was useful to detect 11 different species of LAB. Our results are in agreement with those of other studies where ARDRA is accurate enough to identify species level (Guan et al 2003, Soto et al 2010). However, the bacteria most frequently detected in our experiment were L. salivarius and E. faecalis in contrast with earlier studies where the strains most frequently isolated from the chicken GIT microbiota were Lactobacillus crispatus, Lactobacillus gallinarum, Lactobacillus johnsonii, and Lactobacillus reuteri (Abbas et al 2007, Bjerrum et al 2006, Guan et al 2003). Bacterial diversity and the composition of the microbiota are related to age, rearing environment, production system and diet of chickens (Knarreborg et al 2002, Lu et al 2003). Blood samples were taken during different days in this study because every day, poultry flocks from different farms are slaughtered and it could be an important source of bacterial diversity.

The biopreservation properties of microorganisms are characteristic of each strain, for example some strains have the capacity to produce antimicrobial compounds including organic acids, hydrogen peroxide and bacteriocins (Juárez Tomás et al 2004, Espeche et al 2009), which can inhibit the growth of enteric pathogens. Several studies have reported the antagonistic properties of LAB against many common gastroenteric pathogens, e.g. Salmonella spp, Escherichia coli O157:H7, Clostridium perfringens, Campylobacter jejuni, Listeria monocytogenes and Helicobacter pylori (Mukai et al 2002, Brashears et al 2003, Casey et al 2004, Chaveerach et al 2004, Kim and Chun 2005).

We detected 31 strains from 10 blood samples corresponding to $11 \mathrm{LAB}$ species with different ARDRA profiles, however, the isolates belonging to the same species had a different spectrum of inhibition, suggesting that they were a different strain. Four LAB and three pathogens (DSP collection indicator bacteria, table 3) were used to detect antagonistic activity by $31 \mathrm{LAB}$ isolated from slaughterhouse avian blood. Regarding organic acid production (CFE), only one strain was not affected (L. casei). In contrast, pathogens were highly affected by this substance because these microorganisms are commonly sensitive to low $\mathrm{pH}$. Organic acid production is not always beneficial for food conservation because a decrease in $\mathrm{pH}$ could be harmful regarding the maintenance of the organoleptic characteristics of food or the integrity of plasmatic protein.

Eleven out of these 31 strains showed CFNE with antimicrobial activity. This indicates that the inhibition is due to $\mathrm{H}_{2} \mathrm{O}_{2}$ or bacteriocin production. Regarding $\mathrm{H}_{2} \mathrm{O}_{2}$ production, nine isolates showed positive activity against indicator strains. The release of this substance was positive (inhibition halo $>2 \mathrm{~mm}$ of diameter) and caused inhibition mainly against $P$. fluorescens. The growth inhibition of one bacterial species by the $\mathrm{H}_{2} \mathrm{O}_{2}$ generated by another species is a well-recognised mechanism of bacterial anta- 
gonism (Thompson and Johnston 1950, Dahiya and Speck 1968, Juárez Tómas et al 2004, Patterson et al 2008).

Strains used in this work, such as P. fluorescens, E. coli and Salmonella dublin, are catalase-positive, so the level of $\mathrm{H}_{2} \mathrm{O}_{2}$ should be high to inhibit these pathogens (Zamora Rodríguez 2003). Nevertheless, LAB strains with capacity to inhibit catalase-positive pathogens have been described previously (Gilliland and Speck 1972). However, in the same way as organic acid production, high levels of $\mathrm{H}_{2} \mathrm{O}_{2}$ in food may generate undesirable effects. Peroxides affect lipids and vitamins, causing oxidation, thus decreasing nutritional food quality (Sanders 1994).

On the other hand, only two strains showed antagonistic activity in CFNE but did not produce $\mathrm{H}_{2} \mathrm{O}_{2}$. These were L. salivarius DSPV 027SA and E. faecalis DSPV 008SA. The inhibitory substances generated by these strains were characterised and evaluated to know their inhibition spectrum. The proteinaceous nature of the inhibitory compounds was confirmed because the antibacterial effect did not remain after treatment with proteinase $\mathrm{K}$. Later, detection of EntA gen in E. faecalis DSPV 008SA was confirmed by PCR. Encoding genes were almost studied for enterocins (Cintas et al 1998, Du Toit et al 2000) but the case of salivaricin is more complicated because there is not enough information about bacteriocin types and the genes envolved in their expression. Although production of bacteriocins by L. salivarius has been previously reported (Pilasombut et al 2006, Busarcevic et al 2008) the mode of action of these antimicrobial peptides has not totally elucidated (Pingitore et al 2009).

Then, the antagonistic activity of these substances was tested against other pathogens and spoilage microorganisms probably present in avian blood from slaughterhouse (autochthon indicator bacteria). Results were encouraging because these antimicrobial compounds were able to inhibit many serotypes of Salmonella such as $S$. Agona, S. Brandenburg, Salmonella spp (SA) and Pseuodomonas aeruginosa (SA). It is known that Salmonella spp are very important in avian production because they affect avian health and cause a high impact in human health. On the other hand, Pseudomonas spp. could cause damage in meat products for human consumption and particularly P. aeruginosa is implied in foodborne illness.

L. salivarius showed good characteristics to be used in biopreservation, because it belongs to obligatory homolactic lactobacilli that produce only lactic acid during glucose fermentation. Some clones of L. salivarius are screened for the presence of potential probiotic properties (Martín et al 2006, Hermans et al 2011). Bacteriocin production by mucosal-associated $L$. salivarius strains has been described previously (Ocaña et al 1999, Flynn et al 2002). L. salivarius is considered as a potential probiotic bacterium and can be found in many commercial probiotic products. In a previous research (Barros et al 2009) L. salivarius isolated from chicken showed inhibitory activity against several Salmonella spp. The results in this study demonstrate that L. salivarius DSPV 027SA can inhibit this important pathogen of the avian chain. The probiotic potential of LAB has been related with some evidence of the host-specificity of some members of the indigenous microbiota to colonize specific hosts (Zoetendal et al 2006). The results obtained in this study suggest that $L$. salivarius DSPV 027SA is a good candidate for slaughterhouse blood biopreservation.

E. faecalis DSPV 008SA belongs to the genus Enterococcus, an important group of the LAB generally recognised as safe (GRAS). Different types of enterocins exhibit bactericidal activity against a wide variety of Grampositive bacteria, including food spoilage and pathogenic bacteria such as Bacillus cereus, Clostridium botulinum, Clostridium difficile, Clostridium perfringens, Staphylococcus aureus and Listeria monocytogenes (Mendoza et al 1999, Abriouel et al 2002). E. faecalis also shows activity against some Gram-negative species.

The present study shows that LAB microbiota from slaughterhouse avian blood is diverse and composed of many different species with probiotics or biopreservation potential. Two strains that released antimicrobial compounds were selected (L. salivarius DSPV-027SA and E. faecalis-DSPV 008SA) and they could be suitable for application as biopreservation for avian blood.

However, this potential biopresevation system should be included into the slaughterhouses quality systems (GMP, SSOS, etc.) with the aim to use the avian blood as food or feed additive. This preliminary study allows initiating researches where slaughterhouse avian blood can be used as a functional ingredient in food formulations with technological and health benefits.

\section{ACKNOWLEDGMENTS}

This study is part of the CAI+D Project financed by Universidad Nacional del Litoral, Santa Fe, Argentina. Laureano S. Frizzo and Lorena P. Soto are doctoral fellows and Marcelo L. Signorini is a Research Career Member from the Consejo Nacional de Investigaciones Científicas y Técnicas (CONICET, Argentina). M. Virginia Zbrun is a doctoral fellow from Universidad Nacional del Litoral.

\section{REFERENCES}

Abbas-Hilmi HT, A Surakka, J Apajalahti, PE Saris. 2007. Identification of the most abundant Lactobacillus species in the crop of 1- and 5-week-old broiler chickens. Appl Environ Microbiol 73, 7867-7873.

Abriouel H, M Maqueda, A Gálvez, M Martínez-Bueno, E Valdivia. 2002. Inhibition of bacterial growth, enterotoxin production, and spore outgrowth in strains of Bacillus cereus by bacteriocin AS-48. Appl Environ Microbiol 68, 1473-1477.

Barros MR, RL Andreatti Filho, ET Lima, JA Crocci. 2009. Avaliação in vitro da atividade inibitória de Lactobacillus spp., isolados do inglúvio e cecos de aves sobre Salmone- 
1la. Arq Bras Med Vet Zoot 61, 863-868.

Bjerrum L, RM Engberg, TD Leser, BB Jensen, K Finster, K Pedersen. 2006. Microbial community composition of the ileum and cecum of broiler chickens as revealed by molecular and culture-based techniques. Poul Sci 85, 1151-1164.

Brashears MM, D Jaroni, J Trimble. 2003. Isolation, selection, and characterization of lactic acid bacteria for a competitive exclusion product to reduce shedding of Escherichia coli O157:H7 in Cattle. J Food Protect 66, 355-363.

Busarcevic M, M Kojic, M Dalgalarrondo, JM Chobert, T Haertle, L Topisirovic. 2008. Purification of bacteriocin LS1 produced by human oral isolate Lactobacillus salivarius BGHO1. Oral Microbiol Immunol 23, 254-258.

Carretero C, D Pare's. 2000. Improvement of the microbiological quality of blood plasma for human consumption purposes. Recent Res Devel Agri Food Chem 4, 203-216.

Casey PG, GD Casey, GE Gardiner, M Tangney M, C Stanton, RP Ross, C Hill, GF Fitzgerald. 2004. Isolation and characterization of Anti-Salmonella lactic acid bacteria from the porcine gastrointestinal tract. Lett Appl Microbiol 39, 431-438.

Chaveerach P, LJA Lipman, F van Knapen. 2004. Antagonistic activities of several bacteria on in vitro growth of 10 strains of Campylobacter jejuni/coli. Int J Food Microbiol 90, 43-50.

Chukeatirote A. 2003. Potential use of probiotics. Songklanakarin J Sci Technol 25, 275-282.

Cintas LM, P Casaus, H Holo, PE Hernandez, IF Nes, LS Håvarstein. 1998. Enterocins L50A and L50B, two novel bacteriocins from Enterococcus faecium L50, are related to staphylococcal hemolysins. J Bacteriol, 180, 1988-1994.

Dahiya RS, ML Speck. 1968. Hydrogen peroxide formation by lactobacilli and its effect on Staphylococcus aureus. $J$ Dairy Sci 51, 1568-1572.

Dávila Ribot E. 2006. Advances in animal blood processing: development of a biopreservation system and insights on the functional properties of plasma. Ph. D. Thesis, University of Girona, Girona, Spain.

Delavenne E, R Ismail, A Pawtowski, J Mounier, G Barbier. 2013. Assessment of lactobacilli strains as yogurt bioprotective cultures. Food Control, 30), 206-213.

De Vuyst L, R Callewaert, B Pot. 1996. Characterization of the antagonistic activity of Lactobacillus amylovorus DCE 471 and large scale isolation of its bacteriocin amylovorin L471. Syst Appl Microbiol 19, 9-20.

Du Toit M, CM Franz, LM Dicks, WH Holzapfel. 2000. Preliminary characterization of bacteriocins produced by Enterococcus faecium and Enterococcus faecalis isolated from pig faeces. J Appl Microbiol 88, 482-494.

Espeche MC, MC Otero, F Sesma, ME Nader-Macias. 2009. Screening of surface properties and antagonistic substances production by lactic acid bacteria isolated from the mammary gland of healthy and mastitic cows. Vet Microbiol 135, 346-357.

Flynn S, D van Sinderen, GM Thornton, H Holo, IF Nes, JK Collins. 2002. Characterization of the genetic locus responsible for the production of ABP-118, a novel bacteriocin produced by the probiotic bacterium Lactobacillus salivarius subsp. salivarius UCC118. Microbiol 148, 973-984.

Gilliland S, M Speck. 1972. Interaction of food starter cultures and food-borne pathogens: lactic esptreptococci versus sthaphylococci and salmonellae. J Milk Food Technol 35, 307-310.

Guan LL, KE Hagen, GW Tannock, DR Korver, GM Fasenko, GE Allison. 2003. Detection and identification of Lactobacillus species in crops of broilers of different ages by using PCR-denaturing gradient gel electrophoresis and amplified ribosomal DNA restriction analysis. Appl Environm Microbiol 69, 6750-6757.

Hartemink R, VR Domenech, FM Rombouts. 1997. LAMVAB a new selective medium for the isolation of lactobacilli from feces. J Microbiol Meth 29, 77-84.

Hermans D, KV Deun, W Messens, A Martel, FV Immerseel, F Haesebrouck, G Rasschaert. 2011. Campylobacter control in poultry by current intervention measures ineffective: Urgent need for intensified fundamental research. Vet Microbiol 152, 219-228.

Holzapfel WH. 1997. Use of starter cultures in fermentation on a household scale. Food Control 8, 241-258.

Juárez Tomás MS, MC Otero, VS Ocaña, ME Nader-Macías. 2004. Production of antimicrobial substances in lactic acid bacteria: determination of hydrogen peroxide. Methods Mol Biol 268, 337-346.

Knarreborg A, MA Simon, RM Engberg, BB Jensen, GW Tannock. 2002. Effects of dietary fat source and subtherapeutic levels of antibiotic on the bacterial community in the ileum of broiler chickens at various ages. Appl Environ Microbiol 68, 5918-5924.

Kim M, J Chun. 2005. Bacterial community structure in kimchi, a Korean fermented vegetable food, as revealed by $16 \mathrm{~S}$ rRNA gene analysis. Int J Food Microbiol, 103, 91-96.

Kołozyn-Krajewska, D and ZJ Dolatowski. 2012. Probiotic meat products and human nutrition. Process Biochem 47, 1761-1772.

Kurzak P, MA Ehrmann, RF Vogel. 1998. Diversity of lactic acid bacteria associated with ducks. Syst Appl Microbiol 21, 588-592.

Lu J, U Idris, B Harmon, C Hofacre, JJ Maurer, MD Lee. 2003. Diversity and succession of the intestinal bacterial community of the maturing broiler chicken. Appl Environ Microbiol 69, 6816-6824.

Marmur J. 1961. A procedure for the isolation of deoxyribonucleic acid from microorganisms. J Mol Biol 13, 208-218.

Martín R, E Jiménez, M Olivares, ML Marín, L Fernández, J Xaus, JM Rodríguez. 2006. Lactobacillus salivarius CECT 5713, a potential probiotic strain isolated from infant feces and breast milk of a mother-child pair. Int $J$ Food Microbiol 112, 35-43.

McLean NW, IJ Rosenstein. 2000. Characterization and selection of a Lactobacillus species to re-colonise the vagina of women with recurrent bacterial vaginosis. J Med Microbiol 49, 543-552.

Mendoza F, M Maqueda, A Gálvez, M Martínez-Bueno, E Valdivia. 1999. Antilisterial activity of peptide AS-48 and study of changes induced in the cell envelope properties of an AS-48-adapted strain of Listeria monocytogenes. Appl Environm Microbiol 65, 618-625.

Mukai T, T Asasaka, E Sato, K Mori, M Matsumoto, H Ohori. 2002. Inhibition of binding of Helicobacter pylori to the glycolipid receptors by probiotic Lactobacillus reuteri. FEMS Immunol Medical Microbiol 32, 105-110.

Nettles CG, SF Barefoot. 1993. Biochemical and genetic cha- 
racteristics of bacteriocins of food-associated lactic acid bacteria. J Food Prot 56, 338-356.

Ocaña VS, AA Pesce de Ruiz Holgado, ME Nader-Macías. 1999. Characterization of a bacteriocin-like substance produced by a vaginal Lactobacillus salivarius strain. Appl Environm Microbiol 65, 631-635.

Patterson JL, PH Girerd, NW Karjane, KK Jefferson. 2008. Effect of biofilm phenotype on resistance of Gardnerella vaginalis to hydrogen peroxide and lactic acid. Am J Obstet Gynecol 197, 170.e1-170.e7.

Pilasombut K. 2006. Purification and amino acid sequence of a bacteriocins produced by Lactobacillus salivarius K7 isolated from chicken intestine. Songklanakarin J Sci Technol 28, 121-131.

Pingitore Vera E, EM Hébert, ME Nader-Macías, F Sesma. 2009. Characterization of salivaricin CRL 1328, a twopeptide bacteriocin produced by Lactobacillus salivarius CRL 1328 isolated from the human vagina. Res Microbiol 160, 401-408.

Putnam FW. 1975. The plasma proteins: structure, function, and genetic control. Academic Press, New York, USA.

Reizenstein P. 1980. Hemoglobin fortification of food and prevention of iron deficiency with heme iron. Acta Med Scand 629, 1-46.

Sanders TA. 1994. Nutritional aspects of rancidity. Rancidity in food 128-140.

Schneider R, MR Rosmini, M Ehrmann, R Vogel. 2004. Identificación de bacterias lácticas componentes de la microbiota típica de los terneros criados en condiciones artificiales.
Rev Fac Agr Vet Cs Vet 3, 7-15.

Signorini, ML, E Ponce-Alquicira, I Guerrero-Legarreta. 2006. Effect of lactic acid and lactic acid bacteria on growth of spoilage microorganisms in vacuum-packaged beef. $J$ Muscle Foods 17, 277-290.

Soto L, L Frizzo, E Bertozzi, E Avataneo E, G Sequeira, M Rosmini. 2010. Molecular microbial analysis of Lactobacillus strains isolated from the gut of calves for potential probiotic use. Vet Med Int Volume 2010, Article ID 274987, 7 pages doi:10.4061/2010/274987.

Todorov SD, LMT Dicks. 2006. Screening for bacteriocin-producing lactic acid bacteria from boza, a traditional cereal beverage from Bulgaria Comparison of the bacteriocins. Proc Biochem 41, 11-19.

Thompson R, A Johnston. 1950. The inhibitory action of saliva on the diphtheria bacillus: hydrogen peroxide, the inhibitory agent produced by salivary streptococci. J Infect Dis $88,81-85$.

Zamora Rodríguez LM. 2003. Aislamiento, identificación y conservación de cultivos de bacterias lácticas antagonistas de microbiota contaminante de sangre de matadero. $P h D$ thesis, Institut de Tecnologia Agroalimentària (INTEA), Universidad de Girona, España.

Ziemer CJ, A Cotta, TR Whitehead. 2004. Application of group specific amplified rDNA restriction analysis to characterize swine fecal and manure storage pit samples. Anaerobe 10, 217-227.

Zoetendal EG, EE Vaughan, WM de Vos. 2006. A microbial world within us. Mol Microbiol 59, 1639-1650. 